\title{
Review: Metode Peningkatan Kecepatan Disolusi Dikombinasi Dengan Penambahan Surfaktan
}

\section{(Review: The Different Methods of Enhancing Dissolution Rate by the Present of Surfactant)}

\section{Reynelda Juliani Sagala}

Prodi Farmasi, Fakultas Kedokteran dan Ilmu Kesehatan, Universitas Katolik Atma Jaya, Jakarta 14440, Indonesia

\begin{abstract}
Article Info:
Received: 15 March 2019

in revised form: 28 March 2019

Accepted: 31 March 2019

Available Online: 31 March 2019

Keywords:

Dissolution Rate

Solubility Rate

Surfactant

Therapeutic Effect

Corresponding Author:
Reynelda Juliani Sagala
Prodi Farmasi, FKIK,
Universitas Katolik Atma Jaya
Jakarta, 14440, Indonesia
Mobile : (+62) 82168116846
Email:
reynelda.juliani@atmajaya.ac.id

ABSTRACT

Dissolutionand solubility rates are very important parameters in designing a pharmaceutical dosage form, especially for oral drug administration. Oral drugs that have low dissolution rates often require high doses loading to improve the absorption and effectiveness in order to achieve therapeutic concentration. The increasing of drug dose is a less safe alternative solution, therefore researchers have developed physics, chemistry, and other modification in order to increase dissolution rate. These methods such as salt formation, prodrug formation, particle size reduction (microcrystallization), co-grinding, crystal modification, micellar solubilization and complex formation, solid dispersion and self emulsifying. This review paper will focus on different methods that will be compared with the present of surfactant in these methods. The present of surfactants was able to overcome the limitation of each methods with a mechanism for reducing surface tension, micellar formation, reducing contact angle and increasing of wetting behaviour. Therefore, the present of surfactant in modification of drug dosage form could be considered to increase dissolution rate in order to achieve therapeutic effect.
\end{abstract}

Copyright (C) 2019 JFG-UNTAD This open access article is distributed under a Creative Commons Attribution (CC-BY-NC-SA) 4.0 International license.

How to cite (APA 6th Style):

Sagala, R. J., (2019). Review: Metode Peningkatan Kecepatan Disolusi Dikombinasi Dengan Penambahan Surfaktan. Jurnal Farmasi Galenika : Galenika Journal of Pharmacy, 5 (1), 84-92. doi:10.22487/j24428744.2019.v5.i1.12360. 


\begin{abstract}
ABSTRAK
Kecepatan disolusi dan kelarutan merupakan parameter yang perlu ditentukandalam mendesain suatu sediaan farmasi khususnya obat peroral. Obat oral yang memiliki kecepatan disolusi yang rendah sering membutuhkan dosis yang tinggi untuk memperbaiki absorbsi dan efektivitas obat yang rendah agar mencapai konsentrasi terapeutik. Pengatasan dengan peningkatan dosis obat merupakan alternatif solusi yang kurang aman sehingga peneliti telah banyak melakukan modifikasi fisika, kimia, dan teknik lainnya untuk meningkatkan kecepatan disolusi. Metode peningkatan kecepatan disolusi seperti pembentukan garam, pembentukan prodrug, penurunan ukuran partikel (mikro-kristalisasi) Co-Grinding, modifikasi kristal, solubilisasi miselar dan pembentukan kompleks, dispersi padat, self emulsifying. Pada review tulisan ilmiah ini akan fokus terhadap modifikasi fisik dan kimia yang akan dibandingkan dengan modifikasi fisik dan kimia dikombinasi dengan penambahan surfaktan. Penambahan surfaktan mampu mengatasi kekurangan masing -masing modifikasi dengan mekanisme penurunan tegangan permukaan, pembentukan misel, pengurangan sudut kontak, dan peningkatan pembasahan. Oleh karena itu, penambahan surfaktan dalam memodifikasi sediaan obat dapat meningkatan disolusi obat agar tercapat efek terapetik yang diinginkan.
\end{abstract}

Kata Kunci : Kecepatan Disolusi; Kecepatan Kelarutan; Surfaktan; Efek Terapetik

\section{PENDAHULUAN}

Sediaan farmasi dengan pemberian oral untuk mencapai konsentrasi terapeutik dipengaruhi oleh kecepatan disolusi dan ketersediaan hayati. Pemberian obat secara oral adalah rute pemberian obat yang paling banyak digunakan karena kemudahan pemberiannya. Obat generik yang beredar di Indonesia banyak dalam bentuk sediaan oral dan mendorong perusahaan obat untuk memproduksi obat oral yang bioekivalen. Tetapi, terdapat hambatan utama yaitu obat yang termasuk Biopharmaceutics Classification System (BCS) kelas II (kelarutan rendah dan permeabilitas tinggi) memiliki bioavailibilitas oral yang rendah karena kelarutan obat yang rendah dalam cairan gastrointestinal menyebabkan menunjukkan bahwa absorpsi gastrointestinal yang rendah pula (Lindenberg, Kopp, \& Dressman, 2004). Bioavabilitas sediaan oral tergantung pada beberapa faktor termasuk kelarutan dalam air, permeabilitas obat, tingkat disolusi, dan metabolisme jalur pertama(Ima et al., 2017)

Kecepatan disolusi dan kelarutan merupakan parameter yang sangat penting dalam mendesain suatu sediaan farmasi khususnya obat peroral. Sesuai diagram alir pada gambar 1 , suatu sediaan sebelum diabsorbsi di dalam darah, cairan tubuh lain, dan jaringan. Kelarutan obat merupakan proses awal yang terjadi dalam cairan pencernaan sebelum bahan obat diabsorbsi di tempat absorbsi obat (k1,k2,k3), kemudian (Cartensen, 1977). Sediaan yang tingkat kelarutannya tinggi maka kecepatan disolusi zat aktif dari bentuk sediaan akan lebih cepat, sebaliknya sediaan yang kecepatan disolusinya rendah maka kecepatan disolusi zat aktif dari bentuk sediaan akan lebih lambat, sehingga laju absorbsi obat lebih lambat dan menghasilkan bioavailabilitas yang rendah (Abdou, 1989). Obat oral yang memiliki kecepatan disolusi yang rendah sering membutuhkan dosis yang tinggi untuk memperbaiki absorbsi dan efektivitas obat yang rendah agar mencapai konsentrasi terapeutik(Kusumo \& Mita, n.d.). Pengatasan dengan peningkatan dosis obat merupakan alternatif solusi yang kurang aman sehingga peneliti telah banyak melakukan modifikasi fisika, kimia, dan teknik lainnya untuk meningkatkan kecepatan disolusi.

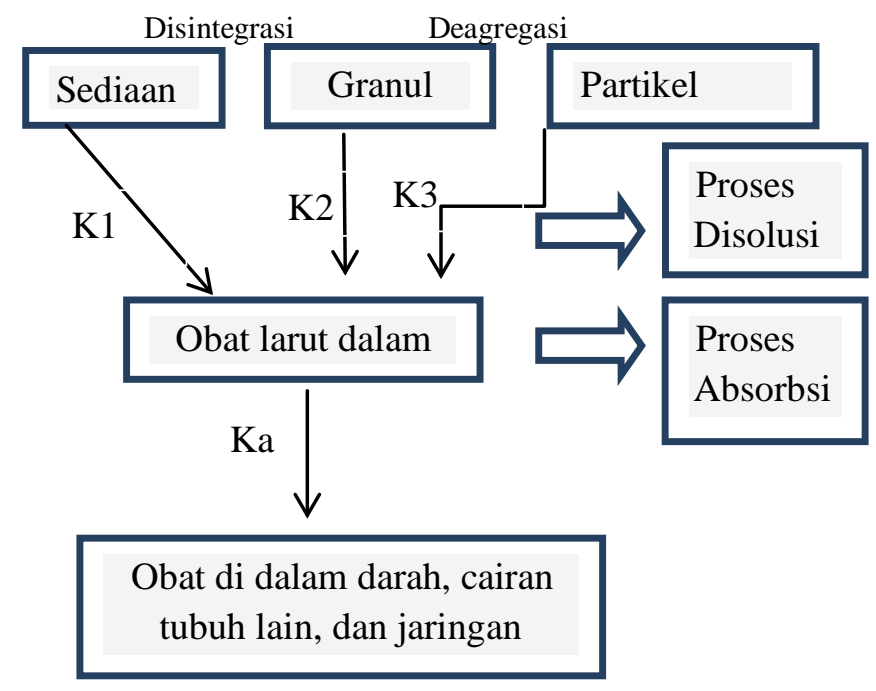

Gambar 1. Skema disintegrasi dan disolusi (Wagner, 1971) 
Modifikasi fisik berupa pengecilan ukuran partikel (mikronisasi \& nanosuspensi), Ko-kristal, dispersi padat (campuran eutektik dan pelarutan), teknik kriogenik. Modifikasi Kimia (Pembentukan garam, penggunaan buffer, perubahan $\mathrm{pH}$, penggunaan adjuvant/surfaktan, penggunaan kosolven, hydrotrophy, dan Supercritical Fluid Process, pembentukan self-emulsifying(Singh et al., 2008).

Pada review tulisan ilmiah ini akan fokus terhadap modifikasi fisik dan kimia yang akan dibandingkan dengan modifikasi fisik dan kimia dikombinasi dengan penambahan surfaktan. Penambahan surfaktan pada formulasi tablet menjadi salah satu modifikasi zat aktif obat untuk meningkatkan kelarutannya yang rendah dalam air. Mekanisme surfaktan dalam meningkatkan kelarutan dengan mengurangi tegangan antar muka, menurunkan sudut kontak, dan meningkatkan pembasahan dengan terjadinya pemindahan fase udara pada permukaan dan menggantikannya dengan suatu fase cair (Martin, Swarbick, \& A, 1993).Mekanisme surfaktan dalam menurunkan tegangan antarmuka antaraobat dan medium memfasilitasi untuk terbentuknya misel yang membawa molekul obat yang telah larut dalam medium. (Martin et al., 1993)

Metode dispersi padat merupakan modifkasi bahan obat dengan pendispersian bahan obat yang sukar larut dalam air ke dalam suatu pembawa yang mudah larut sehingga akan mengurangi ukuran partikel, atau diusahakan terbentuknya polimorf yang lebih mudah larut (Sharma \& Jain, 2010). Self-emulsifying adalah campuran minyak dan surfaktan, yang dapat beremulsi secara spontan untuk menghasilkan partikel emulsi minyak dalam air saat kontak dengan fase air dibawah pengaruh pengadukan (Patil, Praveen, Rani, \& Paradakar, 2005)

Misel akan terbentuk pada penggunaan konsentrasi surfaktan yang lebih tinggi yang akan berkumpul membentuk agregat pada Critical Micelle Concentration (CMC) (Gambar 2). Tempat absorbsi obat, surfaktan dan membran mengandung komponen penyusun yang sama sehingga diasumsikan surfaktan mempu berinteraksi kompleks dengan obat tertentu. (Attwood \& Florence, 1985); (Sudjaswadi, 1991). Kenaikan konsentrasi surfaktan, tegangan permukaan menurun namun ketika telah mencapai CMC maka tegangan permukaan akan selalu tetap meskipun konsentrasi surfaktan ditambah (Martin et al., 1993).
Sedangkan pada kadar yang lebih tinggi surfaktan akan berkumpul membentuk agregat yang disebut misel (Shargel, Wu Pong, \& Yu, 1999) sehingga surfaktan mampu untuk meningkatkan kelarutan zat aktif obat yang rendah.

\section{METODE PENELITIAN}

Pada ulasan ilmiah ini, penulis mencari sumber informasi dan data primer dari internet dengan menggunakan mesin pencari secara online sejumlah jurnal internasional dan nasional. Penelusuran dilakukan secara manual pada daftar pustaka yang relevan sehingga didapatkan sumber pencarian lain seperti menggunakan e-book atau e-journal. Pencarian menggunakan kata kunci: disolusi; kelarutan; dissolution; solubility; bioavailibiltas; surfaktan; dispersi padat; self-emulsifying. Hal-hal yang dipertimbangkan dalam kriteria inklusi dalam pengambilan jurnal sebagai bahan review yang digunakan adalah membandingkan ada atau tidaknya penggunaan surfaktan yang dikombinasi dengan metode modifikasi fisika dan kimia dari sediaan obat dalam perannya meningkatkan kelarutan dan disolusi obat. Kriteria eksklusi yang digunakan adalah metode peningkatan kecepatan disolusi yang tidak menggunakan surfaktan

\section{HASIL DAN PEMBAHASAN}

Kecepatan disolusi merupakan parameter yang menentukan kecepatan absorbsi obat di tempat absorbsi obat yang diinginkan. Beberapa metode yang dapat digunakan untuk meningkatkan kecepatan disolusi adalah pembentukan garam, pembentukan prodrug, penurunan ukuran partikel (mikrokristalisasi) Co-Grinding, modifikasi kristal, solubilisasi miselar dan pembentukan kompleks, modifikasi kristal, solubilisasi miselar dan pembentukan kompleks, dispersi padat. Akan tetapi, terdapat kelemahan dari beberapa metode yang membutuhkan eksipien lain yaitu surfaktan dalam desain sediaan obat tersebut. Hasil penelitian melaporkan bawah beberapa metode peningkatan kecepatan disolusi yang apabila dikombinasi dengan surfaktan mempu menghasilkan jumlah obat yang terdisolusi lebih besar dibandingkan tanpa surfaktan dan menjadikan sediaan lebih stabil, terlihat pada tabel 1. 
Tabel 1. Metode Peningkatan Kecepatan Disolusi dan Keberadaan Surfaktan dalam Modifikasi Metode tersebut

\begin{tabular}{|c|c|c|c|}
\hline $\begin{array}{c}\text { Metode } \\
\text { Peningkatan } \\
\text { Kecepatan } \\
\text { Disolusi }\end{array}$ & Parameter Obat & $\begin{array}{c}\text { Jumlah Obat yang } \\
\text { Terdisolusi }\end{array}$ & Referensi \\
\hline $\begin{array}{l}\text { Pembentukan } \\
\text { garam }\end{array}$ & $\begin{array}{l}\text { 1. Ibuprofen } \\
\text { 2. Natrium Ibuprofen }\end{array}$ & $\begin{array}{l}\text { Setelah menit ke-10: } \\
\begin{array}{l}\text { 1. } 32 \% \\
\text { 2. } 32 \%\end{array}\end{array}$ & $\begin{array}{l}\text { (Hadisoewignyo, } \\
\text { 2009) }\end{array}$ \\
\hline $\begin{array}{l}\text { Pembentukan } \\
\text { prodrug }\end{array}$ & $\begin{array}{ll} & \text { 1. Karbamazepin } \\
\text { 2. } & \text { Prodrug-Karbamazepin-Gli } \\
\text { 3. } & \text { Prodrug-Karbamazepin-Ala } \\
\text { 4. } & \text { Prodrug-Karbamazepin-Lis } \\
\text { 5. } & \text { Campuran fisik-Karbamazepin-Gli } \\
\text { 6. } & \text { Campuran fisik-Karbamazepin-Ala } \\
\text { 7. } & \text { Campuran fisik-Karbamazepin-Lis }\end{array}$ & 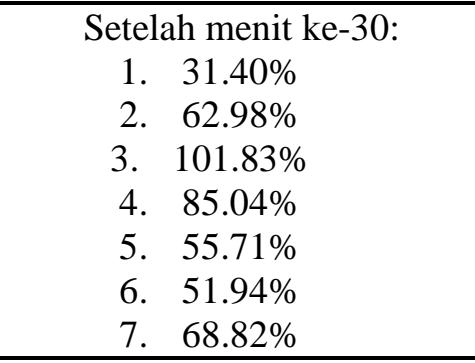 & $\begin{array}{l}\text { (Isadiartuti, } \\
\text { 2015) }\end{array}$ \\
\hline $\begin{array}{l}\text { Penurunan } \\
\text { ukuran } \\
\text { partikel } \\
\text { (mikro- } \\
\text { kristalisasi) } \\
\text { Co-Grinding } \\
\end{array}$ & $\begin{array}{cc} & \text { 1. } \\
\text { 2. } & \text { Ketoprofen } \\
& \text { Campuran Fisik Ketoprofen + } \\
\text { 3. } & \text { Ketoprofen + HPMC }(1: 1) \\
\text { 4. } & \text { Ketoprofen + HPMC }(1: 2) \\
\text { 5. } & \text { Ketoprofen + HPMC }(2: 1) \\
\end{array}$ & 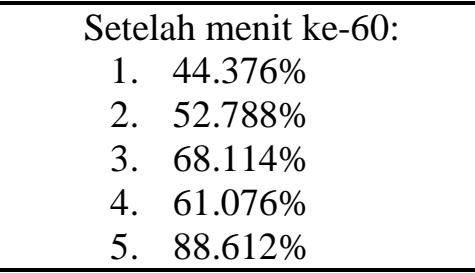 & $\begin{array}{l}\text { (Hilaliyati, Ben, } \\
\text { \& Zaini, 2017) }\end{array}$ \\
\hline $\begin{array}{l}\text { Modifikasi } \\
\text { kristal }\end{array}$ & $\begin{array}{l}\text { 1. } \text { Pirimetamin (PIR) } \\
\text { 2. } \text { Ko-Kristal PIR-FUM }\end{array}$ & $\begin{array}{c}\begin{array}{c}\text { Kelarutan Pirimetamin } \\
\text { (mg/ml): }\end{array} \\
\text { 1. Air: 0.045 } \\
\text { Dapar pH 1.2: 0.978 } \\
\text { Dapar pH 4.5: 2.187 Dapar } \\
\text { pH 6.8: } \\
\text { 0.063 } \\
\text { Kelarutan Ko-kristal PIR- } \\
\text { FUM (mg/ml): } \\
\text { 2. Air: 0.945 } \\
\text { Dapar pH 1.2: } 1.014 \text { (mg/ml) } \\
\text { Air Dapar pH 4.5: 0.636 } \\
\text { Air Dapar pH 6.8: } \\
\text { 0.904 }\end{array}$ & $\begin{array}{c}\text { (Peratiwi et al., } \\
\text { 2018) }\end{array}$ \\
\hline $\begin{array}{c}\text { Solubilisasi } \\
\text { miselar dan } \\
\text { pembentukan } \\
\text { kompleks }\end{array}$ & $\begin{array}{c}\text { 1. Fenilbutazon } \\
\text { Kompleks inklusi Fenilbutazon dengan } \\
\beta \text {-siklodekstrin rasio molar } 1: 1 \\
\text { Kompleks inklusi Fenilbutazon dengan } \\
\beta \text {-siklodekstrin rasio molar } 2: 1 \\
\text { Kompleks inklusi Fenilbutazon dengan } \\
\beta \text {-siklodekstrin rasio molar } 1: 2\end{array}$ & \begin{tabular}{ll}
\multicolumn{2}{l}{ Setelah 60 menit: } \\
1. & $92.115 \%$ \\
2. & $102.228 \%$ \\
3. & $102.195 \%$ \\
4. & $103.747 \%$
\end{tabular} & $\begin{array}{c}\text { (Agustin, } \\
\text { Lestari, \& } \\
\text { Halim, 2015) }\end{array}$ \\
\hline
\end{tabular}




\begin{tabular}{|c|c|c|c|}
\hline Dispersi padat & $\begin{array}{c}\text { 1. Ibuprofen-PVP K90 (1:0.125) } \\
\text { 2. Ibuprofen-PVP K90 (1:0.25) } \\
\text { 3. Ibuprofen-PVP }(1: 0.5)\end{array}$ & $\begin{array}{ll}\text { Setelah } 45 \text { menit: } \\
\text { 1. } & 54.89 \% \\
\text { 2. } & 44.03 \% \\
\text { 3. } & 51.76 \%\end{array}$ & $\begin{array}{c}\text { (Retnowati \& } \\
\text { Setyawan, 2010) }\end{array}$ \\
\hline $\begin{array}{l}\text { Dispersi Padat } \\
+ \text { Surfaktan }\end{array}$ & $\begin{array}{l}\text { 1. Dispersi Padat Ketoprofen-PEG } 4000 \\
\text { dalam } 5 \text { menit } \\
\text {.. Campuran Fisik Ketoprofen-PEG } 4000 \\
\text { 3. Dispersi Padat Ketoprofen-PEG 4000- } \\
\text { Natrium lauril sulfat selama } 5 \text { menit } \\
\text {. Campuran Fisik Ketoprofen-PEG 4000- } \\
\text { Natrium lauril sulfat } \\
\end{array}$ & $\begin{array}{ll}1 . & 56.9 \% \\
\text { 2. } & 29.1 \% \\
\text { 3. } & 72.1 \% \\
\text { 4. } & 56.3 \%\end{array}$ & (Alatas, 2006) \\
\hline \multirow[t]{3}{*}{$\begin{array}{l}\text { Penambahan } \\
\text { surfaktan }\end{array}$} & $\begin{array}{ll}\text { 1. } & \text { Piroxicam-0\% PS } 80 \\
\text { 2. } & \text { Piroxicam-1\% PS } 80 \\
\text { 3. } & \text { Piroxicam-3\% PS } 80 \\
\text { 4. } & \text { Piroxicam-5\% PS } 80\end{array}$ & \begin{tabular}{ll}
\multicolumn{2}{l}{ Setelah 15 menit } \\
1. & $59.51 \%$ \\
2. & $64.31 \%$ \\
3. & $78.43 \%$ \\
4. & $84.12 \%$
\end{tabular} & (Suhesti, 2009) \\
\hline & $\begin{array}{cc}\text { 1. } & \text { Piroxicam-Tween } 1.0 \% \\
\text { 2. } & \text { Piroxicam-Tween } 1.5 \% \\
\text { 3. } & \text { Piroxicam-Tween } 2.0 \% \\
\text { 4. } & \text { Piroxicam-PEG } 4001.0 \% \\
\text { 5. } & \text { Piroxicam-PEG } 4001.5 \% \\
\text { 6. } & \text { Piroxicam-PEG } 4002.0 \%\end{array}$ & $\begin{array}{l}\text { Tetapan Permeabilitas Semu } \\
\begin{array}{ll}\text { (Papp) } \\
\text { 1. } & 0.2591 \\
\text { 2. } & 0.3939 \\
\text { 3. } & 0.3514 \\
\text { 4. } & 0.3866 \\
5 . & 0.2280 \\
6 . & 1.0546 \\
\end{array}\end{array}$ & $\begin{array}{l}\text { (Karim, } \\
\text { Zulkarnain, \& } \\
\text { Kusumawida, } \\
\text { 2008) }\end{array}$ \\
\hline & $\begin{array}{c}\text { 1. Ketoprofen-SLS } 0 \% \\
\text { 2. Ketoprofen-SLS } 0.5 \% \\
\text { 3. Ketoprofen-SLS } 1 \% \\
\text { 4. Ketoprofen-SLS } 1.5 \%\end{array}$ & \begin{tabular}{ll}
\multicolumn{2}{l}{ Setelah 30 menit } \\
1. & $14.641 \%$ \\
2. & $29.668 \%$ \\
3. & $32.063 \%$ \\
4. & $35.814 \%$
\end{tabular} & $\begin{array}{l}\text { (Pratama, } \\
\text { Siswanto, \& } \\
\text { Suparman, } \\
\text { 2012) }\end{array}$ \\
\hline $\begin{array}{l}\text { Mikrokristal } \\
\text { dan } \\
\text { penambahan } \\
\text { surfaktan }\end{array}$ & $\begin{array}{ll}\text { 1. } & \text { Kristal Nifedipin-NLS 1\% } \\
\text { 2. } & \text { Kristal Nifedipin-NLS 3\% } \\
\text { 3. } & \text { Kristal Nifedipin-NLS 5\% } \\
\text { 4. } & \text { Kristal Nifedipin-PLX 1\% } \\
\text { 5. } & \text { Kristal Nifedipin-PLX 3\% } \\
\text { 6. } & \text { Kristal Nifedipin-PLX 5\% }\end{array}$ & $\begin{array}{l}\text { Setelah } 120 \text { menit : } \\
\text { (Surfaktakn NLS): } \\
\text { 1. } 36.74 \% \\
\text { 2. } 31.29 \% \\
\text { 3. } 39.45 \% \\
\text { Surfaktan PLX: } \\
\begin{array}{ll}\text { 4. } & 37.34 \% \\
\text { 5. } & 42.67 \% \\
6 . & 36.60 \%\end{array}\end{array}$ & $\begin{array}{c}\text { (Wikarsa \& } \\
\text { Samaria, 2012) }\end{array}$ \\
\hline $\begin{array}{c}\text { Self } \\
\text { Emulsifying }+ \\
\text { surfaktan }\end{array}$ & $\begin{array}{l}\text { 1. Gliklazid-SLS 1:0.25 } \\
\text { 2. Gliklazid-SLS 1:0.5 } \\
\text { 3. Gliklazid-SLS } 1: 2 \\
\text { 4. Gliklazid-SLS } 1: 4\end{array}$ & $\begin{array}{ll}\text { Setelah } 15 \text { menit : } \\
\text { 1. } & 56.9 \% \\
\text { 2. } & 71.18 \% \\
\text { 3. } & 80.59 \% \\
\text { 4. } & 107.57 \%\end{array}$ & (Anonim, 2013) \\
\hline
\end{tabular}




\section{Surfaktan}

Struktur surfaktan yang menyebabkan adanya afinitas tertentu baik terhadap zat polar maupun nonpolar, dominan hidrofilik, dominan lipofilik, atau berada tepat diantara keduanya. Hal ini menyebabkan zat ini diadsorpsi pada antarmuka cair/gas, cair/cair, dan cair/padat yang akan mengurangi tegangan permukaan atau tegangan antarmuka (Martin et al., 1993). Jenis surfaktan dibagi berdasarkan muatannya yaitu surfaktan anionik, surfaktan kationik, surfaktan nonionik. Surfaktan nonionik yaitu surfaktan dengan alkil yang tidak bermuatan. Jenis surfaktan ini yang banyak digunakan dalam bidang farmasi contohnya polisorbat 80 dengan mekanisme penurunan tegangan antarmuka antara obat dan medium sekaligus membentuk misel yang membawa molekul obat agar larut dalam medium (Gambar 2). Oleh karena itu, jenis surfaktan ini banyak digunakan karena dapat dapat mempercepat waktu hancur dan disolusi tablet (Martin et al., 1993).
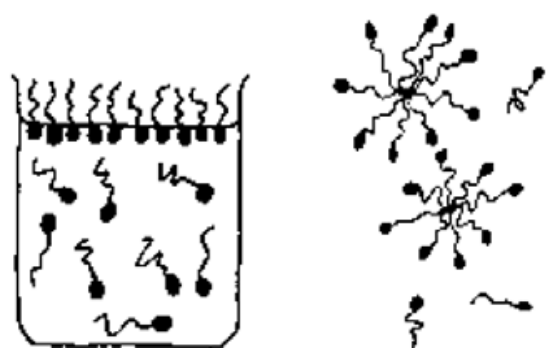

Gambar 2. Pembentukan misel saat kadar surfaktan diatas konsentrasi CMC

\section{Sediaan Obat + Surfaktan}

Surfaktan memiliki kemampuan untuk menurunkan tegangan permukaan, sebagai bahan pembasah, bahan pengemulsi atau emulsifying agent dan bahan pelarut atau solubilizing agent (Ansel, 1989). Obat dengan kelarutan rendah dapat diatasi dengan penambahan eksipien yang dapat meningkatkan kecepatan disolusi tablet yaitu surfaktan, seperti pada penelitian penggunaan polisorbat 80 yang merupakan surfaktan non ionik dapat meningktakan laju disolusi paraetamol dan penambahannya sebanyak 3\% menghasilkan tablet dengan laju disolusi yang paling baik (Najib, 2010). Peningkatan laju disolusi tablet piroxicam juga dilaporkan dengan penambahan polisorbat 80 sebanyak 5\% menghasilkan nilai laju disolusi yang tertinggi. Penelitian yang sama dengan penggunaan SLS yang dapat meningkatkan kecepatan disolusi ketoprofen dan penambahan sebanyak $1.5 \%$ menghasilkan tablet dengan kecepatan disolusi yang paling baik setelah 30 menit. Penambahan eksipien surfaktan atau polimer (Tween atau PEG 400 ) memiliki kemampuan yang serupa dalam meningkatkan laju disolusi Piroxicam.

\section{Sediaan Obat +Mikrokristal (Penurunan Ukuran Partikel)+Polimer+Surfaktan}

Modifikasi ukuran partikel merupakan cara yang paling banyak digunakan dalam meningkatkan kecepatan disolusi, hal ini sesuai dengan persamaan Noyes dan Whitney (1897) yang menyatakan bahwa kecepatan disolusi merupakan suatu ukuran yang menentukan banyaknya suatu zat terlarut dalam pelarut tertentu setiap satuan waktu. Ukuran yang dimaksud merupakan pengurangan ukuran partikel yang baisanya dilakukan dengan mikronisasi. Modifikasi dengan pengecilan ukuran partikel cukup sering dilakukan di industri karena biaya produksi yang lebih rendah, cepat dan mudah dilakukan untuk scale-up. Tetapi, metode ini memiliki kekurangan yang dapat menimbulkan efek elektrostatistik dan distribusi ukuran partikel yang lebar (Chaumeil, 1998). Pemberian energi yang besar dalam proses pengecilan menimbulkan kerusakan kristal yang menyebabkan ketidakstabilan termodinamika kristal (Parrot, 1990). Perubahan sebagian bentuk amorf menjadi bentuk kristal pada permukaan merupakan sifat dari bentuk metode pengecilan ukuran partikel. Perubahan lain seperti aliran, aglomerasi, distribusi partikel yang lebar juga dapat mempengaruhi formulasi. Oleh karena itu, hal ini dapat diatasi dengan penambahan surfaktan yang berperan dalam pembentukan mikrokristal melalui pengendapan antisolvent. Penelitian terhadap laju disolusi kristal Nifedipin yang ditambah dengan surfaktan NLS dan PLX. Surfaktan ini sebagai stabilisator yang mencegah terbentuknya aglomerat melalui pembentukan lapisan permukaan mikrokristal nifedipin yang terbentuk dan meningkatkan pembasahan kristal (Rasenack \& Müller, 2004).

\section{Sediaan Obat + Dispersi Padat + Surfaktan}

Istilah sistem dispersi padat didefenisikan sebagai dispersi lebih dari satu senyawa obat dalam matriks inert yang dibentuk dalam keadaan padat dengan metode pelarutan, pelelehan atau gabungan keduanya (PVP disolusi surktn). Teknik dispersi padat meningkatkan solubilisasi, pembasahan, mengecilkan ukuran partikel, dan menghambat terjadinya kristalisasi bahan obat. Penggunaan polimer dalam 
teknik dispersi padat kurang praktis untuk bahan obat yang memiliki dosis relatif besar $(\geq 100 \mathrm{mg})$ karena peningkatan laju disolusi sangat dipengaruhi oleh jumlah polimer, sehingga akan membutuhkan polimer dalam jumlah yang besar. Oleh karena itu masalah ini dapat diatasi dengan pembentukan sistem terner dengan penambahan surfaktan yang dapat mengurangi penggunaan polimer dan meningkatkan laju disolusi.(Hartono, n.d.)

Penelitian oleh Fikri (2006), kelarutan ketoprofen ditingkatkan dengan penambahan PEG 4000 dan dengan atau tanpa penambahan surfaktan. Hasil penelitiannya menunjukkan bahwa sistem dispersi padat ketoprofen-PEG 4000-SLS memiliki laju disolusi yang lebih baik daripada sistem dispersi padat ketoprofen-PEG 4000. Penelitian dengan penambahan SLS sebagai surfaktan dalam formulasi tablet ketoprofen dengan variasi konsentrasi (SLS) dapat meningkatkan kelarutan ketoprofen.

\section{Sediaan Obat Self-emulsifying+ Surfaktan}

Pengadukan minyak dan surfaktan yang membentuk emulsi spontan yang menghasilkan partikel emulsi minyak dalam air saat kontak dengan fase air(Patil et al., 2005). Dalam bidang formulasi teknologi sediaan padat seperti pembuatan tablet, granul, dan pellet self-emulsifying metode ini menjadi pilihan yang perli dipertimbangkan dalam pengubahan bentuk cair self-emulsifying menjadi bentuk padat/serbuk (solid self-emulsifying).Pembuatan sediaan mikropartikel self-emulsifying dengan menggunakan surfaktan dapat menurunkan ukuran partikel derajat kristalinitas serta meningkatkan kelarutan dan kecepatan disolusi obat.

\section{KESIMPULAN}

Laju absorbsi obat oral sangat tergantung kecepatan disolusi zat aktif dari bentuk sediaanya. Apabila laju disolusi obat yang rendah maka diperlukan dosis yang lebih besar untuk mencapai dosis terapetik, oleh karena itu modifikasi menjadi pilihan efektif dalam meningkatkan disolusi yaitu dengan metode fisika, kimia, dan teknik lain. Tetapi, beberapa metode memiliki kekurangan seperti mikrokristal (penurunan ukuran partikel) dapat menimbulkan efek elektrostatistik, aglomerasi dan distribusi obat yang tidak homogen. Metode lain seperti dispersi padat yang kurang praktis untuk bahan obat yang memiliki dosis relatif besar ( $\geq 100 \mathrm{mg}$ ). Metode self-emulsfying kurang efektif dalam menghasilkan bentuk serbuk.
Penambahan surfaktan mampu mengatasi kekurangan masing- masing modifikasi dengan mekanisme penurunan tegangan permukaan, pembentukan misel, pengurangan sudut kontak, dan peningkatan pembasahan. Oleh karena itu, penambahan surfaktan dalam memodifikasi sediaan obat dapat meningkatan disolusi obat agar tercapat efek terapetik yang diinginkan.

\section{DAFTAR PUSTAKA}

Abdou, H . (1989). Dissolution, Bioavailability and Bioequivalence. Easton: Mack Publishing Comp.

Agustin, R., Lestari, F. I., \& Halim, A. (2015). ABSTRAK Fenilbutazon merupakan obat Anti Inflamasi Non Steroid (NSAID) dan diklasifikasikan dalam kelas II dari. KartikaJurnal Ilmiah Farmasi, 3(1), 14-19.

Alatas, F. (2006). Pengaruh konsentrasi PEG 4000 terhadap laju disolusi ketoprofen dalam sistem dispersi padat ketoprofen-PEG 4000, 17(2), 57-62.

Anonim. (2013). Pengembangan Sistem Penghantaran Obat Solid Self-Emulsifying Mikropartikel Gliklazid untuk Meningkatkan Disolusi. Majalah Ilmu Kefarmasian, 8(1), 4857.

Ansel, H. . (1989). Pengantar Bentuk Sediaan Farmasi. Jakarta: UI Press.

Attwood, D., \& Florence, A. . (1985). Surfactan System (I). London, New York: Chapman and Hall.

Cartensen, J. (1977). Pharmaceutics of Solids Dosage and Solid dosage Form. A Wiley Interscience Publication John, (New York:John Wiley and Sons), 133-135, 154-159, 216-218.

Chaumeil, J. (1998). Micronization: A Method of Improving The Bioavailability of Poorly Soluble Drugs. Meth.Find. Exp. Clin. Pharmacol, 20, 211-215.

Hadisoewignyo, L. (2009). Pembuatan garam ibuprofen dan aplikasinya dalam sediaan tablet dosage form, 20(3), 141-150.

Hartono, E. P. (n.d.). Skripsi Pengaruh Poloxamer 
188 terhadap Disolusi Alopurinol dalam Dispersi Padat Alopurinol-PVP K-30Poloxamer 188. Universitas Airlangga.

Hilaliyati, N., Ben, E. S., \& Zaini, E. (2017). Peningkatan Laju Disolusi Ketoprofen dengan Teknik Co-grinding Menggunakan Polimer Hidroksipropil Metilselulosa E6. Jurnal Sains Farmasi \& Klinis, 3(May), 193-201.

Ima, A., Patihul, D., Studi, P., Apoteker, P., Farmasi, F., \& Padjadjaran, U. (2017). Artikel Tinjauan: Teknik Meningkatkan Kelarutan Obat. Farmaka, 15, 49-57.

Isadiartuti, D. (2015). Disertasi Pembentukan Prodrug Karbamazepin-Asam Amino sebagai Upaya Memperbaiki Sifat Fisikokimia dan Bioavailabilitas Karbamazepin. Universitas Airlangga.

Karim, A., Zulkarnain, A. K., \& Kusumawida, A. (2008). Pengaruh penambahan tween 80 dan poli- etilen glikol 400 terhadap absorpsi piroksikam melalui lumen usus in situ The influence of tween 80 and polyethylen glycol 400 on piroxicam absorption from rat intestinal lumen in situ, 19(1), 25-31.

Kusumo, N. N., \& Mita, S. R. (n.d.). Review: Pengaruh Natural Binder pada Hasil Granulasi Parasetamol. Farmaka, Suplemen V, 228-235.

Lindenberg, M., Kopp, S., \& Dressman, J. B. (2004). Classification of orally administered drugs on the World Health Organization Model list of Essential Medicines according to the biopharmaceutics classification system, 58, 265-278.

Martin, A., Swarbick, J., \& A, C. (1993). Farmasi Fisik 2 (Edisi III). Jakarta: UI Press.

Najib, A. (2010). Studi Komparasi Terhadap Laju Disolusi Tablet Parasetamol dengan Penambahan Polisorbat 80. Universitas Muslim Indonesia, Makassar.

Parrot, E. (1990). Comminution. In: Swarbrick, J., Boylan, J.C. (Eds). In Encyclopedia of Pharmaceutical Technology (Vol 3, p. pp.101121). Marcel Decker, New York.

Patil, P., Praveen, S., Rani, R., \& Paradakar, A.
(2005). Bioavailability Assessment of Ketoprofen Incorporated in Gelled SelfEmulsifying Formulation. A. Technical Note. AAPS, 1, E9-E13.

Peratiwi, R. P., Alatas, F., Wahyuni, F., Sugandi, R., Ratih, H., \& Hermanto, F. (2018). Pengaruh Pembentukan Ko-Kristal Pirimetamin-Asam Fumarat terhadap Kelarutan dan Laju Disolusinya. Kartika-Jurnal Ilmiah Farmasi, 4(1)(June 2016), 31-36.

Pratama, A. W., Siswanto, A., \& Suparman. (2012). Pengaruh Penambahan Sodium Lauril Sulfat (SLS) sebagai Surfaktan terhadap Sifat Fisik dan Uji Disolusi Tablet Ketoprofen. Pharmacy, 09(03), 11-22.

Rasenack, N., \& Müller, B. W. (2004). Micron-Size Drug Particles: Common and Novel Micronization Techniques. Pharmaceutical Development and Technology, 9(1), 1-13.

Retnowati, D., \& Setyawan, D. (2010). Peningkatan Disolusi Ibuprofen dengan Sistem Dispersi Padat Ibuprofen-PVP, (April).

Shargel, L., Wu Pong, S., \& Yu, A. B. . (1999). Applied Biopharmaceutics and Pharmacokinetics (5th ed.). Singapore: Mc.Graw and Hill.

Sharma, A., \& Jain, C. (2010). Preparation and characterization of solid dispersions of carvedilol with PVP K30. Research in Pharmaceutical Sciences, 5(1), 49-56.

Singh, A., Chaurasiya, A., Singh, M., Upadhyay, S., Mukherjee, R., \& Khar, K. (2008). Exemestane Loaded Self-Microemulsifying Drug Delivery System (SMEDDS). Development and Optimization. AAPS9, 2, 628-634.

Sudjaswadi, R. (1991). Tween 80 dan Stabilitas Asetosal. Majalah Farmasi Indonesia, 2, 2834.

Suhesti, T. S. (2009). Optimasi formula sediaan tablet piroksikam menggunakan bahan flowlac , avicel dan compritol secara Simplex Lattice Design Optimization of piroxicam tablet formula using flowlac , 20(3), 156-162.

Wagner, J. . (1971). Biopharmaceutics and Relevant 
Pharmacokinetics (Edisi I). Hamilton: Drug Intellegen Publication.

Wikarsa, S., \& Samaria, F. (2012). Peningkatan Disolusi Nifedipin dari Mikrokristalnya yang Dibuat Melalui Pengendapan Antisolvent dengan Keberadaan Poloxamer 188 atau Natrium Lauril Sulfat, XXXVII(3), 110-115. 